\title{
Article
}

\section{Proses Pemekaran Tabir Raya Kabupaten Merangin Menjadi Kabupaten Baru}

\author{
Miranti 1*, Arifin ${ }^{2}$
}

This article is an open access article distributed under the terms and conditions of the Creative Commons Attribution-ShareAlike 4.0 International (CC BY SA ) License (https://creativecommo ns.org/licenses/by$\underline{\mathrm{sa} / 4.0 /)}$

\section{Jurnal Politik dan} Pemerintahan Daerah ISSN 2686-2271

Fakultas Ilmu Sosial dan Ilmu Politik, Universitas Muara Bungo Jl. Diponegoro No. 27, Muara Bungo-Jambi, (0747) 323310

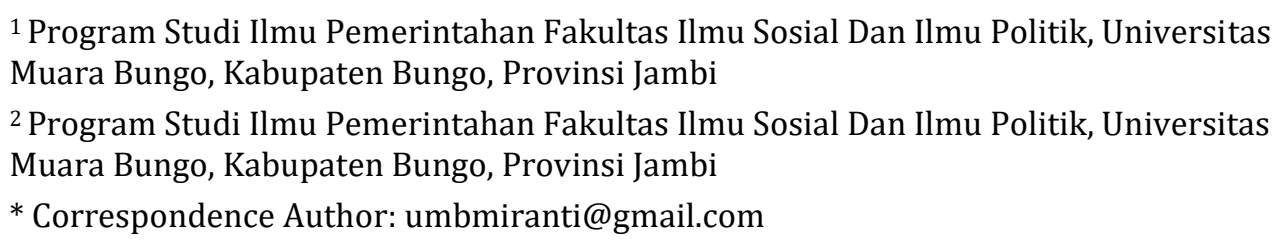

Abstract: The purpose of this study was to determine the process of expanding Tabir Raya Merangin Regency into a new district and to determine the inhibiting factors and efforts to overcome barriers to the expansion of Tabir Raya into a district. The method used in this research is a qualitative research method with a descriptive study. The method used in this research is a qualitative research method with a descriptive study. The informant selection technique used by the researcher in this study was to use the purposive sampling method (sampling technique with certain considerations). The results of this study indicate that the process of dividing Tabir Raya Regency from Merangin Regency has been running for approximately 10 years, from the initiation, meeting, fundraising, academic study, parent district approval, Merangin Regency DPRD approval, approval from the Jambi Provincial Government and approval from DPRD , until the process is carried out at the Ministry of Home Affairs, and regional mapping. The inhibiting factors for the expansion of Tabir Raya Regency from Merangin Regency are limited funds in making maps, so that map making is slow, and the Tabir Raya Expansion Team has not been published in trying to overcome obstacles in the expansion of Tabir Raya. Raya from Merangin Regency. This effort is supported by the Merangin Regency Government, which is serious about establishing the Tabir Raya Regency. Efforts are being made to accelerate the making of maps and the issuance of Government Regulations.

Keywords: Process, Expansion, Tabir Raya

Abstrak: Tujuan dilakukan penelitian ini adalah untuk mengetahui proses pemekaran Tabir Raya Kabupaten Merangin menjadi kabupaten baru dan untuk mengetahui faktor-faktor penghambat dan upaya mengatasi hambatan pemekaran Tabir Raya menjadi kabupaten. Metode yang digunakan dalam penelitian ini penelitian ini adalah metode penelitian kualitatif yang bersifat dengan studi deskriptif. Metode yang digunakan dalam penelitian ini penelitian ini adalah metode penelitian kualitatif yang bersifat dengan studi deskriptif. Teknik pemilihan informan yang digunakan oleh peneliti dalam penelitian ini adalah dengan menggunakan metode purposive sampling (teknik penentuan sampel dengan pertimbangan tertentu). Hasil penelitian ini menunjukkan bahwa proses pemekaran Kabupaten Tabir Raya dari Kabupaten Merangin telah berjalan lebih kurang 10 tahun, dari tahapan inisiasi, rapat, penggalangan dana, Kajian Akademis, Persetujuan kabupaten induk, persetujuan DPRD Kabupaten Merangin, persetujuan dari Pemerintah Provinsi Jambi dan Persetujuan dari DPRD, hingga dilakukan proses di Kementerian Dalam Negeri, dan pemetaan wilayah.Faktor penghambat pemekaran Kabupaten Tabir Raya dari Kabupaten Merangin adalah terbatasnya dana dalam pembuatan peta, sehingga pembuatan peta 
menjadi lamban, serta belum terbitnya Tim Pemekaran Tabir Raya dalam berusaha untuk mengatasi hambatan dalam pemekaran Tabir Raya dari Kabupaten Merangin. Upaya tersebut didukung Pemerintah Kabupaten Merangin yang serius mengupayakan pembentukan Kabupaten Tabir Raya. Upaya yang dilakukan adalah, percepatan pembuatan peta dan penerbitan Peraturan Pemerintah.

Kata Kunci : Proses, Pemekaran, Tabir Raya

\section{Pendahuluan}

Era reformasi telah memberikan ruang yang lebih terbuka kepada masyarakat untuk mengembangkan dan membangun dirinya sendiri. Hal ini memunculkan berbagai fenomena keinginan masyarakat pada berbagai wilayah untuk membentuk daerah otonom baru, baik daerah provinsi maupun kabupaten atau kota. Keinginan tersebut didasari terjadinya dinamika di daerah itu sendiri baik dinamika sosial, ekonomi, politik maupun budaya.

Dinamika perkembangan wilayah menjadi otonom seperti itu disikapi pemerintah pusat dengan diberlakukannya kebijakan otonomi sejak tahun 1999 yang lalu. Dalam pembentukan daerah otonom, mulanya diilhami oleh pasal 18 UUD 1945 yang antara lain menyatakan bahwa pembagian daerah Indonesia atas besar dan kecil, dengan bentuk dan susunan pemerintahannya ditetapkan dengan undang-undang. Daerah Indonesia akan dibagi dalam daerah provinsi dan daerah provinsi dibagi lagi menjadi daerah kabupaten atau daerah kota. Otonomi daerah, sebagai salah satu produk dari era reformasi, merupakan strategi untuk merespon tuntutan masyarakat untuk mengembangkan dan membangun dirinya sendiri. Yang dimaksud dengan otonomi daerah adalah pemerintah pusat tidak lagi memgang kendali atas fungsi tertentu dalam pemerintahan dan mengalihkan fungsi tersebut sebagai wewenang daerah untuk menciptakan lapisan baru dalam pemerintah (Seymour \& Turner, 2002).

Sejalan dengan banyaknya keinginan untuk melakukan pembentukan daerah otonom baru, baik berupa pemekaran maupun peningkatan status, khususnya di daerah kabupaten dan kota sesuai dengan mekanisme pembentukan daerah otonom maka pemerintah telah mengeluarkan Peraturan Pemerintah Nomor 129 tahun 2000. Peraturan pemerintah tersebut berisi tentang persyaratan Pembentukan dan Kriteria pemekaran, penghapusan dan penggabungan daerah, yang isinya antara lain menyebutkan persyaratan, kriteria, prosedur, pembiayaan pemekaran, penghapusan dan penggabungan daerah. Pembentukan daerah otonom ini, diharapkan mampu memanfaatkan peluang yang lebih besar dalam mengurus rumah tangganya sendiri, terutama dalam kaitannya dengan sumbersumber pendapatan asli daerah, sumber daya alam dan pengelolaan bantuan pemerintah pusat kepada daerah otonom dalam rangka meningkatkan kesejahteraan dan pelayanan kepada masyarakat setempat lebih baik.

Otonomi daerah, secara konseptual memperlihatkan adanya perubahan yang signifikan pada model dan paradigma pemerintahan daerah. Model dan paradigma yang sebelumnya pelayanan publik dari wewenang pemerintah pusat berubah menjadi Model efisiensi struktural (structural efficiency model). Model pelayanan publik dari wewenang pemerintah pusat adalah model yang memberikan penekanan pada efisiensi dan keseragaman dalam penyelenggaraan pemerintahan pusat. Sedangkan model efisiensi struktural (structural efficiency model) lebih menekankan pada efisiensi dan keseragaman dalam penyelenggaraan pemerintahan daerah.

Seiring dengan pergeseran model tersebut, terjadi pula pergeseran dari penekanan aspek sentralisasi kepada penekanan aspek desentralisasi. Sistem 
pemerintahan yang ada di era otonomi daerah saat ini dengan asas desentralisasi merupakan suatu refleksi proses reformasi sosial, ekonomi, politik maupun budaya di Indonesia memiliki kecenderungan dan pergeseran pelayanan publik dari wewenang pemerintah pusat menjadi kewenangan pemerintahan daerah yang lebih dekat dengan masyarakatnya.

Dalam perspektif otonomi daerah ini, kekuasaan akan terbagi antara pemerintah pusat dan pemerintah daerah yang secara legal konstitusional tetap dalam kerangka Negara Kesatuan Republik Indonesia (NKRI) Dalam mendukung implementasi kebijakan ekonomi daerah itu, pemerintah telah mengatur dalam Undang-undang Republik Indonesia Nomor 23 Tahun 2014 tentang Pemerintahan Daerah Bab VI Penataan Daerah Pasal 31, menyebutkan, "Penataan Daerah ditujukan untuk; mewujudkan efektivitas penyelenggaraan Pemerintahan Daerah, mempercepat peningkatan kesejahteraan masyarakat, mempercepat peningkatan kualitas pelayanan publik, meningkatkan kualitas tata kelola pemerintahan, meningkatkan daya saing nasional dan daya saing Daerah, dan memelihara keunikan adat istiadat, tradisi, dan budaya Daerah" (Pemerintah Republik Indonesia, 2014).

Lalu, pada Bab I Pasal 2 ayat 9 disebutkan, "Negara mengakui dan menghormati kesatuan-kesatuan masyarakat adat beserta hak tradisionalnya sepanjang masih hidup dan sesuai dengan perkembangan masyarakat dan prinsip Negara Kesatuan Republik Indonesia."

Berdasarkan ketentuan-ketentuan tersebut maka dapat dijelaskan bahwa keinginan masyarakat daerah untuk membentuk daerah otonom baru memang dimungkinkan oleh peraturan perundangan yang berlaku. Sebelum adanya otonomi daerah, pemerintah pusatlah yang mengatur semua kebijakan termasuk mengenai kebijakan daerah yang dinilai tidak sesuai dengan kultur budaya daerahdaerah tertentu (Risal, 2017). Hal ini perlu dikelola dengan baik sehingga tidak menimbulkan benturan-benturan dan masalah yang akan terjadi sebagai akibat dari keinginan masyarakat daerah itu sendiri.

Seiring dengan perkembangan dinamika di berbagai daerah dan peraturan pendukung yang ada, masyarakat Tabir yang terdiri dari 8 kecamatan juga mengajukan pembentukan daerah otonomi tersendiri. Hal ini terjadi karena melihat peraturan perundang-undangan mengenai pemerintahan daerah yang berlaku saat itu (Undang-undang Nomor 32 Tahun 2004 dan Peraturan Pemerintah Republik Indonesia Nomor 78 Tahun 2007 Tentang Tata Cara Pembentukan, Penghapusan, Dan Penggabungan Daerah), sedemikian memberikan kemungkinan untuk dilakukannya pemekaran satu daerah otonom menjadi beberapa daerah otonom baru. Hal ini juga menegaskan komitmen Negara Kesatuan Republik Indonesia ini yang memberikan ruang bagi terpeliharanya warisan sejarah dan kultur dari sebuah daerah seperti Kabupaten Tabir Raya yang senama dengan sungai yang melintasi daerah tersebut.

Selain dari peraturan perundang-undangan tersebut, juga adanya wilayah yang terlalu luas dan banyaknya kecamatan untuk dikelola dalam satu wilayah pemerintahan. 24 (dua puluh empat) Kecamatan yang terdapat di wilayah Kabupaten Merangin tersebut, direncanakan dimekarkan menjadi 2 (dua) Kabupaten dengan pembagian 16 (enam belas) Kecamatan tetap di kabupaten induk dan 8 (delapan) Kecamatan di kabupaten pemekaran. Sebagaimana terlihat pada tabel berikut ini:

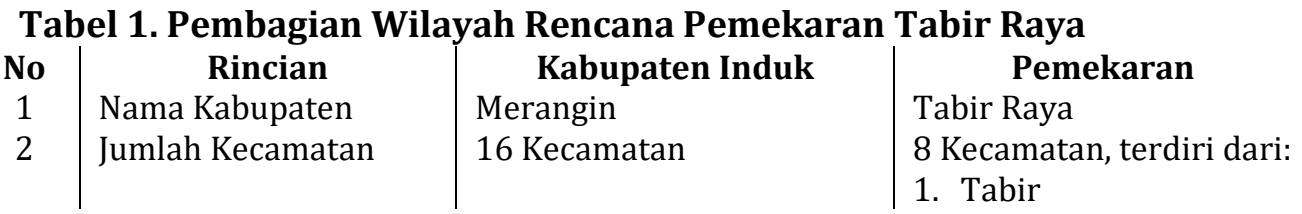




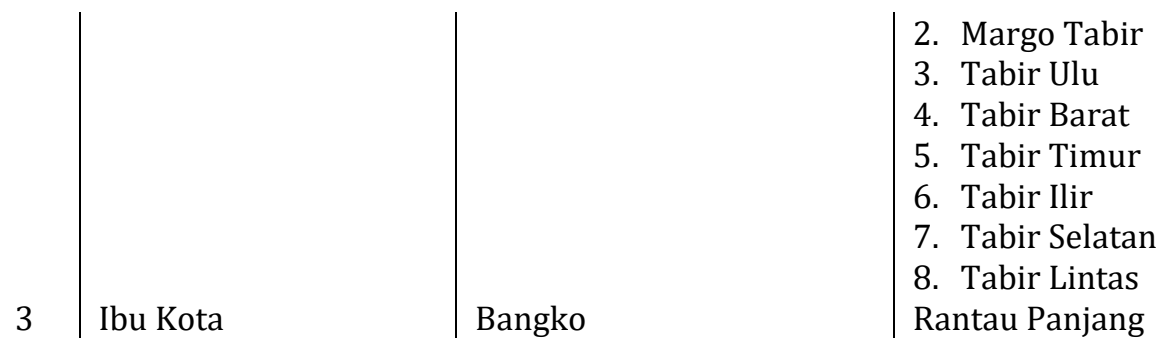

Sumber : Sekretariat Tim Pemekaran Tabir Raya, 2018

Pemekaran Kabupaten Tabir Raya tersebut menjadi wajar dengan harapan akan membawa berbagai keuntungan bagi masyarakat, seperti fasilitas sosial, ekonomi dan finansial untuk kepentingan kesejateraan masyarakat pada masa depan bagi daerah yang baru dimekarkan.

Melihat keinginan masyarakat di delapan Kecamatan yang terhimpun dalam Tabir Raya tersebut, pada satu sisi, pemekaran wilayah sangat diperlukan karena kondisi sosial, ekonomi, yang belum merata, juga karena kondisi geografis antara satu wilayah kecamatan dengan wilayah kecamatan sangat jauh dan terlalu luas. Dengan demikian pemekaran wilayah diharapkan dapat memacu perkembangan sosial, ekonomi, peningkatan kualitas demokrasi, mengurangi kesenjangan dan menjaga kelestarian lingkungan hidup pada suatu wilayah. Namun di sisi lain, perkembangan pemekaran wilayah ini masih menimbulkan beberapa persoalan utama, yaitu penentuan batas-batas wilayah geografis dan administratif wilayah baru dan hal ini selalu memberikan dampak sosial, politik dan ekonomi serta distribusi aset negara pada wilayah-wilayah baru tersebut.

Sejak dibentuk Tim Pemekaran Tabir Raya pada tahun 2008 lalu hingga berjalan 10 tahun hingga sekarang (2018), Kabupaten Tabir Raya belum juga terbentuk, berbagai upaya telah dilakukan baik dari musyawarah tingkat desa yang dimekarkan, pertemuan antar kecamatan, pengumpulan dana, penyiapan tim negosiasi baik level pemerintah dan DPRD Kabupaten Merangin maupun Pemerintah dan DPRD Provinsi Jambi hingga pemerintah dan DPR RI Pusat.

Berdasarkan hasil wawancara, diketahui beberapa faktor penghambat dalam pemekaran Tabir Raya diantaranya yaitu masih ada syarat yang belum terpenuhi, syarat yang belum dipenuhi tersebut yang merupakan syarat mutlak itu adalah peta wilayah calon Daerah Otonomi Baru (DOB) dan peta wilayah kabupaten induk. Sejauh ini pemerintah Merangin baru mampu memetakan wilayah 119 Desa. Total desa di Merangin tercatat 205 desa dan 10 kelurahan, selain itu pemerintah pusat juga meminta peta wilayah terbaru.

Menurut Tim Pemekeran Tabir Raya tersebut dirinya tidak bisa memastikan kapan realisasi pemekaran itu akan terjadi. Sebab semua ditentukan oleh pemerintah pusat, selain itu ada tahapan yang diikuti oleh calon kabupaten baru. Menjawab pertayaan masyarakat Tabir, kapan pemekaran itu terlaksana itu teknisnya pemerintah pusat. Karena yang memproses dan menetukannya pemerintah pusat. Yang jelas secara Adminitrasi tidak ada kendala lagi, kami juga optimistis pemetaan ini secepat mungkin akan selesai," pungkasnya (Tim Pemekar Tabir Raya, Wawancara, 12 Januari 2018).

Pemekaran wilayah Kabupaten Merangin dan Tabir Raya yang sedang hangat-hangatnya dibicarakan sekarang ini, baik dari gerakan pro dan kontra pada masyarakat yang sedemikian beragam dan kompleks ini, sedemikian menarik untuk diteliti secara ilmiah mengenai pemekaran wilayah Kabupaten Merangin dan Tabir Raya. Berdasarkan uraian diatas maka penulis tertarik untuk meneliti lebih lanjut mengenai "PROSES PEMEKARAN TABIR RAYA KABUPATEN MERANGIN MENJADI KABUPATEN BARU”. 


\section{Pembahasan}

\section{Proses Pemekaran Tabir Raya Kabupaten Merangin Menjadi Kabupaten Baru}

Latar belakang pemekaran Kabupaten Tabir Raya akan dijelaskan dalam penelitian ini dengan tujuan agar dapat mengetahui perihal alasan yang mendorong masyarakat Tabir untuk melakukan pemekaran menjadi Kabupaten. Melalui penjelasan ini kemudian akan dianalisis terkait latar belakang pemekaran Kabupaten Tabir Raya.

Pada awalnya masyarakat Tabir mengusulkan adanya pemekaran untuk mempercepat laju pembangunan dan pertumbuhan ekonomi, hingga setara dengan daerah otonomi lain yang mekar telah terlebih dahulu melakukan pemekaran. Dengan adanya pemekaran Kabupaten Tabir Raya diharapkan juga memberikan dampak yang positif untuk pelaksanaan pembangunan sarana dan prasarana dalam pemerintahan akan semakin berkembang dan lebih efektif, dengan demikian pelayanan publik juga lebih dekat dengan masyarakat guna mewujudkan kesejahteraan masyarakat.

Kondisi tersebut menujukan bahwa yang pemekaran Tabir Raya merupakan keinginan dari masyarakat yang terhimpun dalam rumpun Kecamatan Tabir agar kecamatan Tabir, yang ingin terjadinya perubahan pembangunan di wilayah Tabir, karena merasa Kabupaten Merangin terlalu luas, ada 24 kecamatan, tentu menjadi kendala sendiri bagi pemerintah Kabupaten Merangin, dengan adanya pemekaran tersebut pembangunan lebih dapat terarah.

Keinginan masyarakat untuk mekar juga didasari dari ketimpangan pembangunan yang dilakukan Pemerintah Merangin dimana pembangunan lebih banyak di arahkan ke Kecamatan Jangkat dan kecamatan sekitarnya, dengan alasan terpencil dan banyak produksi hasil pertanian dari kecamatan tersebut serta adanya objek wisata, sementara kecamatan Tabir Barat juga tergolong kedalam terpencil, infrastruktur jalan ke Tabir Barat juga lebih parah lagi buruknya, dan di Tabir Barat juga terdapat objek wisata, hanya saja akses menuju ke sana jalannya jelek, sehingga masyarakat malas mengunjunginya.

Kecenderungan yang dipertimbangkan untuk memekarkan daerah Tabir Raya adalah terkait dengan pertimbangan pemerataan pembangunan dan secara geografis dinilai terlalu luas serta di satu sisi diharapkan pemekaran Tabir Raya akan mampu memperlancar roda pemerintahan kedepan, baik itu eksekutif maupun legislatif. Di sisi lain, pembangunan sarana prasana yang pendukung, dapat mempercepat pertumbuhan ekonomi masyarakat.

Terlihat jelas harapan dari masyarakat wilayah Tabor sebagaimana digambarkan di atas yang berharapa dengan adanya pemekaran Tabir Raya pembangunan jadi merata, sehingga terwujud pembangunan jalan ke Tabir Barat karena kita sudah punya anggaran sendiri, dengan adanya sarana prasarana yang baik diharapkan pertumbuhan ekonomi masyarakat jadi meningkat, hasil pertanianpun dapat dijual dengan baik, karena jalannya (infrastruktur) sudah bagus.

Pemekaran merupakan cara untuk memperpendek rentang kendali serta menciptakan pemerataan pembangunan yang berkeadilan dan kesejahteraan, konsentrasi pembangunan yang tidak merata sehingga masyarakat beranggapan pemerintah induk tidak mampu menjawab persoalan-persoalan rakyat secara konsisten, jauhnya jarak pelayanan publik kepada masyarakat dan kurangnya konsentrasi pembangunan yang tidak merata yang dilakukan oleh pemerintah induk harusnya dijadikan tantangan oleh pemerintah induk untuk dicarikan solusinya, dan diharapkan upaya-upaya bagi kekuasaan semestinya tidak menjadi alasan yang selama ini dijadikan kekuatan sebagai bentuk aspirasi.

Rencana pemekaran Kabupaten Tabir Raya dari Kabupaten Merangin, hanya mengambil 8 (delapan) kecamatan dalam wilayah Kabupaten Merangin, dimana kecamatan tersebut merupakan pecahan dari kecamatan Induk Tabir yang terdiri 
dari Tabir, Margo Tabir, Tabir Ulu, Tabir Barat, Tabir Timur, Tabir Ilir, Tabir Selatan, dan Tabir Lintas. Pemilihan nama Tabir Raya didasari pertimbangan bahwa setiap kecamatan tersebut dilalui Sungai Batang Tabir dan penggunaan kata Tabir dalam nama kecamatan. Pemekaran wilayah Tabir Raya sudah direncakan dari awal untuk delapan kecamatan, yang terhimpun dalam Kecamatan Tabir dan Sekitarnya, dimana delapan kecamatan tersebut merupakan kecamatan pemekaran dari kecamatan Tabir

Proses pemekaran Kabupaten Tabir Raya dari Kabupaten Merangin telah berjalan lebih kurang 10 tahun, dari tahapan inisiasi, rapat, penggalangan dana, persetujuan kabupaten induk, persetujuan DPRD Kabupaten Merangin, persetujuan dari Pemerintah Provinsi Jambi dan Persetujuan dari Pemerintah Pusat, hingga dilakukan proses di Kementerian Dalam Negeri.

1. Inisiasi

Keinginan pemekaran ini berasal dari tokoh-tokoh masyarakat, tokoh pemuda dan tokoh adat yang bersatu ingin mewujudkan terbentuknya Kabupaten Tabir Raya.

Keinginan masyarakat untuk terjadinya pemekaran telah dimulai sejak tahun 2008, kondisi tersebut dipengaruhi oleh rencana pemekaran Kabupaten Kerinci, dimana Kabupaten Kerinci mekar menjadi Kabupaten Kerinci dan Kota Sungai Penuh, sehingga masyarakat terinspirasi oleh pemekaran tersebut, banyak tokoh masyarakat yang berpikir untuk memekarkan Kabupaten Merangin menjadi dua kabupaten, karena Kecamatan yang ada di Tabir ini cukup untuk memenuhi syarat pemekaran.

2. Rapat

Adanya kesamaan pemahaman dan visi masyarakat beserta tokoh masyarakat yang ada dalam wilayah Tabir, maka dilanjutkan dengan beberapat pertemuan dalam bentuk rapat guna mendengarkan aspirasi dan rencana jangka panjang terhadap upaya pemekaran Kabupaten Tabir Raya. Rapat yang sering dilaksanakan akhirnya membuahkan hasil sehingga dapat mengundang tokoh masyarakat dalam wilayah Tabir dan sekitarnya untuk mengikuti rapat besarbesaran di Kantor Camat Tabir yang ketika itu dihadiri oleh beberapa Kepala Desa dan BPD, tokoh masyarakat, pimpinan Pondok Pesantren. Pertemuan-pertemuan yang berawal dari balai-balai (tempat masyarakat mengobrol yang terbuat dari papan, sejenis bangku panjang), warung kopi, terus berkembang hingga pertemuan di beberapa tempat hajatan pernikahan hingga acara yasinan.

Hasil dari beberapa kali pertemuan hingga Rapat di Kantor Camat Tabir memutuskan untuk membentuk Tim kecil yang diberi tugas melakukan penggalangan dana untuk proses pemekaran Kabupaten Tabir Raya dari Kabupaten Merangin.

3. Pengalangan Dana

Sebagai bentuk kesungguhan masyarakat dan tokoh masyarakat dalam wilayah Tabir dilakukan penggalangan dana dari berbagai elemen masyarakat, yang digunakan untuk operasional tim Pemekaran Kabupaten Tabir Raya dari Kabupaten Merangin. Penggalangan dana, dana tersebut kita kumpulkan dari berbagai elemen masyarakat, kita juga melakukan pemungutan kepada PNS yang ada di dalam wilayah Tabir dengan sumbangan tersebut memperoleh dana awal kita 2 juta lebih, tim kecil juga meminta sumbangan terhadap para toke getah dan toke sawit yang ada dalam wilayah Tabir.

Dengan dana yang ada, tim mulai bergerak dengan melakukan berbagai pertemuan dan lobi guna mencari dukungan dari berbagai 
pihak, baik pemerintah daerah maupun pemerintah pusat, berbagai tokoh masyarakat Tabir yang ada di Provinsi Jambi dan di Pusat dilakukan komunikasi agar mendapatkan arahan dan bimbingan serta pencarian solusi terhadap proses dan permasalahan yang terjadi.

Sehubungan dengan dan yang telah ada, maka tim leluasa untuk bergerak dan melakukan berbagai kunjungan serta lobi berbagai unsur tokoh masyarakat dihubungi dan diadakan diskusi guna memperoleh gambaran dan langkah yang harus dilakukan dalam proses pemekaran Tabir Raya dari Kabupaten Merangin, baik itu tokoh masyarakat Tabir yang ada di Provinsi Jambi maupun yang ada di Pusat.

4. Tim Pemekaran Tabir Raya

Pada tanggal 6 September 2013 diadakan rapat Tim Formatur yang bertempat di Rumah Bapak Zakaria dengan agenda Pembentukan Tim Pemekaran Kabupaten Tabir Raya yang dihadiri berbagai unsur masyarakat dalam wilayah delapan kecamatan Tabir, sehingga dihasilkan susunan Tim Panitia Pemekaran 8 Kecamatan Tabir dalam Kabupaten Merangin menjadi Kabupaten Tabir Raya sebagai berikut:

\section{a. Dewan Penasehat}

Dewan Penasehat berjumlah 54 orang yang terdiri dari berbagai tokoh masyarakat yang ada dalam wilayah Tabir, baik dari unsur Pemerintahan, Tokoh masyarakat dari berbagai kalangan dan profesi, yang diharapkan mampu memberikan pengarahan dan pandanganya serta masukannya demi terwujudnya Kabupaten Tabir Raya.

b. Pengurus

Adapun susunan pengurus Tim Panitia Pemekaran 8 Kecamatan Tabir dalam Kabupaten Merangin menjadi Kabupaten Tabir Raya terdiri dari:

\begin{tabular}{|c|c|}
\hline Ketua & Drs. H. Zakaria Saleh \\
\hline Wakil Ketua I : & Burhan, S.Pd.I, MM \\
\hline Wakil Ketua II : & Mukhtar YS \\
\hline Wakil Ketua III : & Bunyamin \\
\hline Wakil Ketua IV : & Saipan Amruansyah, SE \\
\hline Wakil Ketua V & Zainudin Ilyas \\
\hline Wakil Ketua VI : & Sutrisno \\
\hline Sekretaris Umum & Jailani, S.Sos \\
\hline Sekretaris I & Ade Sadria \\
\hline Sekretaris II & Sutardi, S.pd.I \\
\hline Sekretaris III : & Ngatijan, SE \\
\hline Sekretaris IV & Nurim, S.Kom \\
\hline Sekretaris V & Nori Novita Sari \\
\hline Bendahara Umum & Jalaludin, S.Pd \\
\hline
\end{tabular}


Wakil Bendahara $\quad$ : $\quad$ Muhammad Sidin, A.Md

c. Bidang-bidang

1). Kesekretariatan

2). Pendanaan

3). Kajian Hukum

4). Dokumentasi dan Ekspos Media

5). Humas.

5. Kajian Akademis

6). Penggalangan Massa

Kajian Akademis merupakan salah satu syarat untuk sebuah wilayah dimekarkan, kajian akademis bertujuan untuk mengkaji sejauh mana sebuah daerah layak untuk dimekarkan berdasarkan indikator yang telah ditetapkan. Kajian akademis itu untuk mengukut sejauh mana suatu daerah tersebut layak dimekarkan dengan beberapa indikator, karena akademisi bersifat netral, makanya perlu akademisi yang melakukan kajiannya supaya tidak subjektif dalam penilaian uji kelayakan pemekaran suatu daerah. Hasil dari kajian akademis memberikan tiga opsi dalam pemekaran daerah Kabupaten Merangin, dengan berbagai pertimbangan dan nilai yang diperoleh dari indikator tersebut, pemaparan itulah yang jadi pertimbangan tim dan pihak pusat.

Disamping itu pengkajian ini juga dimaksudkan untuk memenuhi syarat teknis, sebagaimana yang tersebut dalam Pasal 5 ayat (4) Undang Undang Nomor 32 Tahun 2004 bahwa pemekaran daerah dapat dilakukan berdasarkan syarat teknis yang mencakup faktor kependudukan, kemampuan ekonomi, potensi daerah, sosial budaya, sosial politik, luas daerah, pertahanan, keamanan, tingkat kesejahteraan masyarakat dan rentang kendali yang memungkinkan terselenggaranya Otonomi Daerah. Dalam penjelasan ketentuan dimaksud disebutkan pula bahwa pembentukan, pemekaran, penghapusan dan penggabungan daerah otonom memerlukan penilaian dengan menggunakan indikator yang tersedia.

Hasil ekspose akhir Kajian Akademis Pembentukan Daerah Otonom Baru (Pemekaran Wilayah) Kabupaten Merangin Provinsi Jambi yang dilakukan oleh Tim Pemerintah Kabupaten Merangin Bekerjasama dengan Institut Pemerintahan Dalam Negeri-Kemendagri pada Tahun 2015, yang diketuai oleh Prof. Dr. Sadu Wasistiono, MS selaku Guru Besar Manajemen Pemerintahan dan Otonomi Daerah, diperoleh 5 opsi dalam pemekaran daerah di Kabupaten Merangin. Analisis Potensi pada wilayah Kabupaten Merangin menggunakan 2 analisis yaitu menurut kententuan PP Nomor 129 Tahun dengan 19 variabel dan PP Nomor 78 Tahun 2007 dengan 11 variabel. Maka dapat simpulkan sebagai berikut :

Tabel 1. Hasil Analisis Potensi Wilayah Kabupaten Merangin

\begin{tabular}{l|l|l|r|l|l} 
No & Kabupaten & Kecamatan & Total Skor & \multicolumn{1}{|c|}{ Interval Skor } & Kategori \\
1 & Merangin & Jangkat & 786 & $644 \leq \mathrm{TS}<1.008$ & Cukup Layak \\
2 & & 1031 & $1.008 \leq \mathrm{TS}<1.680$ & Layak \\
3 & & Sungai Tenang & 986 & $644 \leq \mathrm{TS}<1.008$ & Cukup Layak \\
4 & & Muara Siau & 779 & $644 \leq \mathrm{TS}<1.008$ & Cukup Layak \\
5 & & Lembah Masurai & 1047 & $1.008 \leq \mathrm{TS}<1.680$ & Layak \\
6 & & Tiang Pumpung & 1041 & $1.008 \leq \mathrm{TS}<1.680$ & Layak \\
7 & & Pamenang & 958 & $644 \leq \mathrm{TS}<1.008$ & Cukup Layak
\end{tabular}




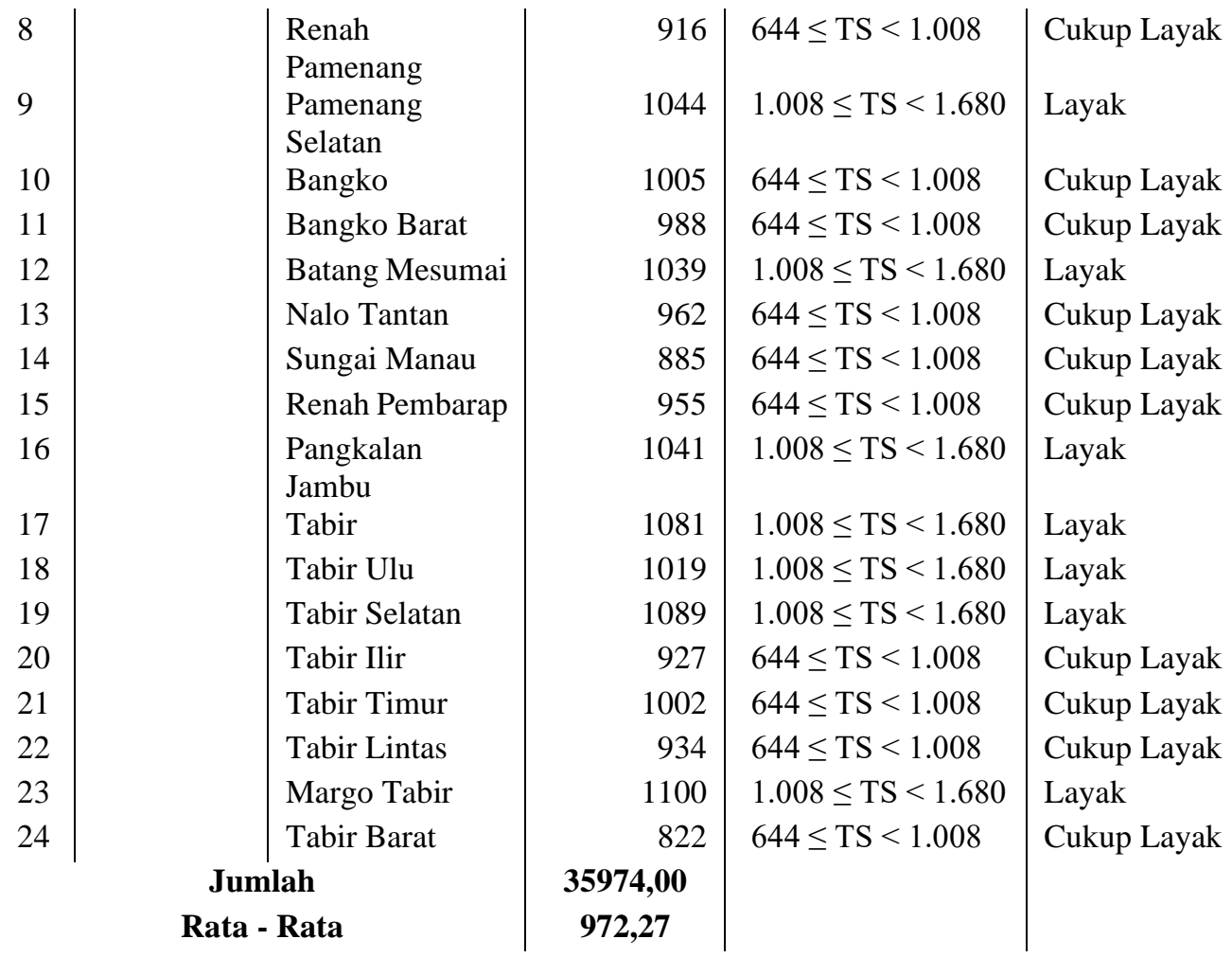

Sumber : Tim Pemekaran Kabupaten Tabir Raya, 2018

Tabel 2. Alaternatif 1 Pemekaran Kabupaten Merangin

\begin{tabular}{|c|c|c|c|c|c|}
\hline $\begin{array}{c}\text { Kabupaten } \\
\text { Baru }\end{array}$ & $\begin{array}{l}\text { Kecamatan } \\
\text { Nominatif }\end{array}$ & $\begin{array}{l}\text { Skor } \\
\text { Total }\end{array}$ & $\begin{array}{l}\text { Kabupaten } \\
\text { Lama }\end{array}$ & $\begin{array}{c}\text { Kecamatan } \\
\text { Nominatif }\end{array}$ & $\begin{array}{l}\text { Skor } \\
\text { Total }\end{array}$ \\
\hline 1 & Tabir Barat & 822 & Merangin & Jangkat & 786 \\
\hline 2 & Tabir Ulu & 1.019 & & Sungai Tenang & 1.031 \\
\hline 3 & Tabir Lintas & 934 & & Muara Siau & 986 \\
\hline 4 & Tabir Selatan & 1.089 & & Lembah Masurai & 779 \\
\hline 5 & Tabir & 1.081 & & Tiang Pumpung & 1.047 \\
\hline 6 & Margo Tabir & 1.100 & & Pamenang & 1.041 \\
\hline 7 & Tabir Ilir & 927 & & Pamenang Barat & 958 \\
\hline 8 & Tabir Timur & 1.002 & & Renah Pamenang & 916 \\
\hline 9 & & & & Pamenang Selatan & 1.044 \\
\hline 10 & & & & Bangko & 1.005 \\
\hline 11 & & & & Bangko Barat & 988 \\
\hline 12 & & & & Batang Mesumai & 1.039 \\
\hline 13 & & & & Nalo Tantan & 962 \\
\hline 14 & & & & Sungai Manau & 885 \\
\hline 15 & & & & Renah Pembarap & 955 \\
\hline 16 & & & & Pangkalan Jambu & 1.041 \\
\hline \multicolumn{2}{|c|}{ Jumlah } & 7.974 & & & 15.463 \\
\hline \multicolumn{2}{|c|}{ Rata-Rata } & 997 & & & 966 \\
\hline \multicolumn{2}{|c|}{ Total Skor Minimal } & 822 & & & 779 \\
\hline \multicolumn{2}{|c|}{ Total Skor Maksimal } & 1.100 & & & 1.047 \\
\hline
\end{tabular}

Sumber : Tim Pemekaran Kabupaten Tabir Raya, 2018 
Berdasarkan analisis potensi wilayah Kabupaten Merangin yang diperoleh sebagaimana terlihat pada tabel di atas, maka Pemetaan kecamatan wilayah Kabupaten Merangin pada skenario 1 (alternatif 1) yaitu kabupaten lama dengan kecamatan nominatif adalah Jangkat, Sungai Tenang, Muara Siau, Lembah Masurai, Tiang Pumpung, Pamenang, Pamenang Barat, Renah Pamenang, Pamenang Selatan, Bangko, Bangko Barat, Batang Mesumai, Nalo Tantan, Sungai Manau, Renah Pembarap dan Pangkalan Jambu. Kabupaten baru dengan kecamatan nominatif adalah Tabir Barat, Tabir Ulu, Tabir Lintas, Tabir Selatan, Tabir, Margo Tabir, Tabir Ilir dan Tabir Timur.

Tabel 3. Alaternatif 2 Pemekaran Kabupaten Merangin

\begin{tabular}{|c|c|c|c|c|c|c|}
\hline No & $\begin{array}{c}\text { Kabupaten } \\
\text { Baru }\end{array}$ & $\begin{array}{c}\text { Kecamatan } \\
\text { Nominatif }\end{array}$ & Skor Total & $\begin{array}{c}\text { Kabupaten } \\
\text { Lama }\end{array}$ & $\begin{array}{l}\text { Kecamatan } \\
\text { Nominatif }\end{array}$ & $\begin{array}{l}\text { Skor } \\
\text { Total }\end{array}$ \\
\hline 1 & & Tabir Barat & 822 & Merangin & Jangkat & 786 \\
\hline 2 & & Tabir Ulu & 1.019 & & Sungai Tenang & 1.031 \\
\hline 3 & & Tabir Lintas & 934 & & Muara Siau & 986 \\
\hline 4 & & Tabir Selatan & 1.089 & & Lembah Masurai & 779 \\
\hline 5 & & Tabir & 1.081 & & Tiang Pumpung & 1.047 \\
\hline 6 & & Margo Tabir & .100 & & Pamenang & 1.041 \\
\hline 7 & & Tabir Ilir & 927 & & Pamenang Barat & 958 \\
\hline 8 & & Tabir Timur & 1.002 & & Pamenang Selatan & 1.044 \\
\hline 9 & & Nalo Tantan & 962 & & Bangko & 1.005 \\
\hline 10 & & Renah Pembarap & 955 & & Bangko Barat & 988 \\
\hline 11 & & Sungai Manau & 885 & & Batang Mesumai & 1.039 \\
\hline 12 & & Pangkalan Jambu & 1.041 & & Renah Pemenang & 916 \\
\hline \multicolumn{3}{|c|}{ Jumlah } & 11.817 & & & 11.620 \\
\hline \multicolumn{3}{|c|}{ Rata - Rata } & 985 & & & 968 \\
\hline \multicolumn{3}{|c|}{ Total Skor Minimal } & 822 & & & 779 \\
\hline \multicolumn{3}{|c|}{ Total Skor Maksimal } & 1.100 & & & 1.047 \\
\hline
\end{tabular}

Sumber : Tim Pemekaran Kabupaten Tabir Raya, 2018

Berdasarkan analisis potensi wilayah Kabupaten Merangin yang diperoleh sebagaimana terlihat pada tabel di atas, maka Pemetaan kecamatan wilayah Kabupaten Merangin pada skenario 2 yaitu kabupaten lama dengan kecamatan nominatif adalah Jangkat, Sungai Tenang, Muara Siau, Lembah Masurai, Tiang Pumpung, Pamenang, Pamenang Barat, Pamenang Selatan, Bangko, Bangko Barat, Batang Mesumai, dan Renah Pamenang. Kabupaten baru dengan kecamatan nominatif adalah Tabir Barat, Tabir Ulu, Tabir Lintas, Tabir Selatan, Tabir, Margo Tabir, Tabir Ilir, Tabir Timur, Nalo Tantan, Renah Pembarap, Sungai Manau, dan Pangkalan Jambu.

Tabel 4. Alaternatif 3 Pemekaran Kabupaten Merangin

\begin{tabular}{l|l|c|r|r|r|r} 
No & $\begin{array}{c}\text { Kabupaten } \\
\text { Baru }\end{array}$ & $\begin{array}{c}\text { Kecamatan } \\
\text { Nominatif }\end{array}$ & $\begin{array}{c}\text { Skor } \\
\text { Total }\end{array}$ & $\begin{array}{c}\text { Kabupaten } \\
\text { Lama }\end{array}$ & $\begin{array}{c}\text { Kecamatan } \\
\text { Nominatif }\end{array}$ & $\begin{array}{c}\text { Skor } \\
\text { Total }\end{array}$ \\
1 & & Tabir Barat & 822 & Merangin & Jangkat & 786
\end{tabular}




\begin{tabular}{|c|c|c|c|c|}
\hline & Tabir Ulu & 1.019 & Sungai Tenang & 1.031 \\
\hline & Tabir Lintas & 934 & Muara Siau & 986 \\
\hline & $\begin{array}{l}\text { Tabir } \\
\text { Selatan }\end{array}$ & 1.089 & $\begin{array}{l}\text { Lembah } \\
\text { Masurai }\end{array}$ & 779 \\
\hline & $\begin{array}{l}\text { Pamenang } \\
\text { Barat }\end{array}$ & 958 & $\begin{array}{l}\text { Tiang } \\
\text { Pumpung }\end{array}$ & 1.047 \\
\hline & Pamenang & 1.041 & $\begin{array}{l}\text { Renah } \\
\text { Pamenang }\end{array}$ & 916 \\
\hline & Margo Tabir & 1.100 & $\begin{array}{l}\text { Pamenang } \\
\text { Selatan }\end{array}$ & 1.044 \\
\hline & Tabir & 1.081 & Bangko & 1.005 \\
\hline & Tabir Ilir & 927 & Bangko Barat & 988 \\
\hline 0 & Tabir Timur & 1.002 & $\begin{array}{l}\text { Batang } \\
\text { Mesumai }\end{array}$ & 1.039 \\
\hline 1 & & & Nalo Tantan & 962 \\
\hline 2 & & & Sungai Manau & 885 \\
\hline 3 & & & $\begin{array}{l}\text { Renah } \\
\text { Pembarap }\end{array}$ & 955 \\
\hline & & & $\begin{array}{l}\text { Pangkalan } \\
\text { Jambu }\end{array}$ & \\
\hline \multicolumn{2}{|c|}{ Jumlah } & 9.973 & & 13.464 \\
\hline \multicolumn{2}{|c|}{ Rata - Rata } & 997 & & 962 \\
\hline \multicolumn{2}{|c|}{ Total Skor Minimal } & 822 & & 779 \\
\hline \multicolumn{2}{|c|}{ Total Skor Maksimal } & 1.100 & & 1.047 \\
\hline
\end{tabular}

Sumber : Tim Pemekaran Kabupaten Tabir Raya, 2018

Berdasarkan analisis potensi wilayah Kabupaten Merangin yang diperoleh sebagaimana terlihat pada tabel di atas, maka Pemetaan kecamatan wilayah Kabupaten Merangin pada skenario 3 yaitu kabupaten lama dengan kecamatan nominatif adalah Jangkat, Sungai Tenang, Muara Siau, Lembah Masurai, Tiang Pumpung, Renah Pamenang, Pamenang Selatan, Bangko, Bangko Barat, Batang Mesumai, Nalo Tantan, Sungai Manau, Renah Pembarap, dan Pangkalan Jambu. Kabupaten baru dengan kecamatan nominatif adalah Tabir Barat, Tabir Ulu, Tabir Lintas, Tabir Selatan, Pamenang Barat, Pamenang, Margo Tabir, Tabir, Tabir Ilir, dan Tabir Timur.

\section{Tabel 5. Alaternatif 4 Pemekaran Kabupaten Merangin}

\begin{tabular}{c|c|l} 
No & $\begin{array}{c}\text { Kab. } \\
\text { Baru I }\end{array}$ & $\begin{array}{l}\text { Kecamatan } \\
\text { Nominatif } \\
1\end{array}$ \\
2 & & Tabir Barat \\
& & Tabir Ulu \\
3 & & Tabir \\
4 & & Selatan \\
5 & & Tabir Lintas \\
& & Margo \\
6 & & Tabir \\
7 & & Tabir \\
& & Tabir Ilir
\end{tabular}

\begin{tabular}{r|} 
Skor \\
Total \\
822 \\
1.019 \\
\\
1.089 \\
\\
934 \\
1.100 \\
1.081 \\
927
\end{tabular}

\begin{tabular}{|l|}
\multicolumn{1}{|c}{ Kecamatan } \\
Nominatif \\
Jangkat \\
Lembah \\
Masurai \\
Sungai Tenang \\
Muara Siau \\
Tiang Pumpung \\
Pamenang \\
Selatan
\end{tabular}

\begin{tabular}{r|} 
Skor \\
Total \\
786 \\
779 \\
\\
1.031 \\
\\
986 \\
1.047 \\
1.044 \\
\end{tabular}

Kab.
Lama
Merangin

\begin{tabular}{|l|}
\multicolumn{1}{|c|}{ Kecamatan } \\
Nominatif \\
Pamenang \\
Pamenang \\
Barat \\
Renah \\
Pamenang \\
Bangko \\
Bangko Barat \\
Batang \\
Mesumai \\
Nalo Tantan
\end{tabular}

Skor Total 1.041 958 


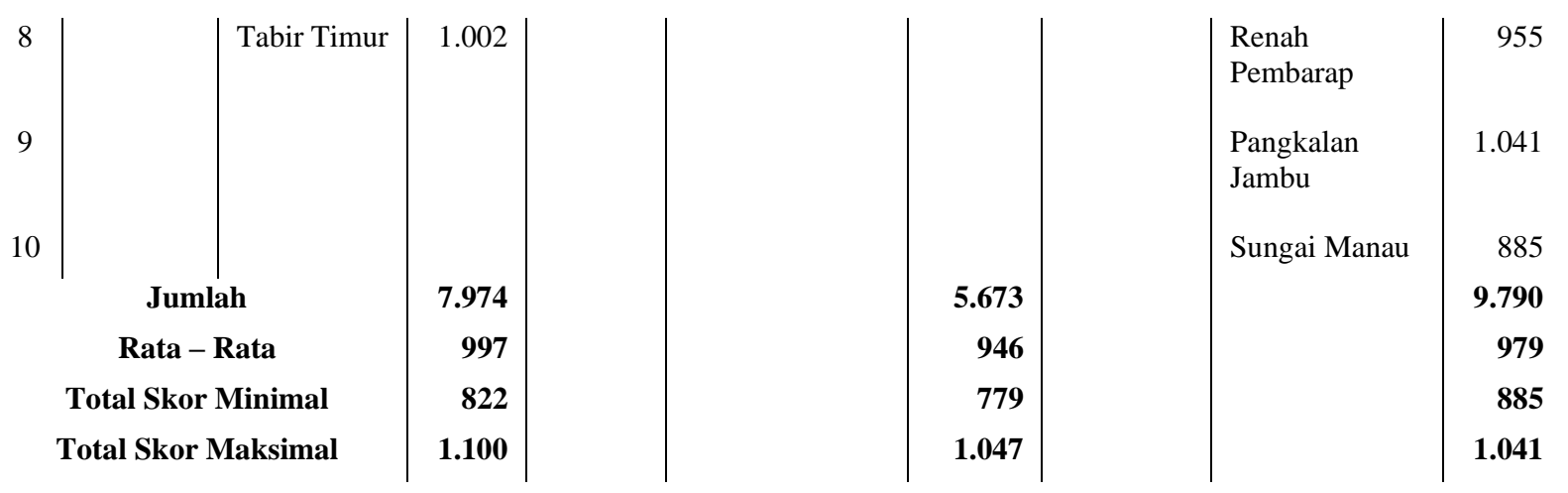

Sumber : Tim Pemekaran Kabupaten Tabir Raya, 2018

Berdasarkan analisis potensi wilayah Kabupaten Merangin yang diperoleh sebagaimana terlihat pada tabel di atas, maka Pemetaan kecamatan wilayah Kabupaten Merangin pada skenario 4 yaitu kabupaten lama dengan kecamatan nominatif adalah Pamenang, Pamenang Barat, Renah Pamenang, Bangko, Bangko Barat, Batang Mesumai, Nalo Tantan, Renah Pembarap, Pangkalan Jambu, dan Sungai Manau. Kabupaten baru yang pertama dengan kecamatan nominatif adalah Tabir Barat, Tabir Ulu, Tabir Selatan, Tabir Lintas, Margo Tabir, Tabir, Tabir Ilir, dan Tabir Timur. Kabupaten baru yang kedua dengan kecamatan nominatif adalah Jangkat, Lembah Masurai, Sungai Tenang, Muara Siau, Tiang Pumpung, dan Pamenang Selatan.

Tabel 6. Alaternatif 5 Pemekaran Kabupaten Merangin

\begin{tabular}{|c|c|c|c|c|c|c|c|c|c|}
\hline No & $\begin{array}{l}\text { Kab. } \\
\text { Baru I }\end{array}$ & $\begin{array}{c}\text { Kecamatan } \\
\text { Nominatif }\end{array}$ & $\begin{array}{l}\text { Skor } \\
\text { Total }\end{array}$ & $\begin{array}{l}\text { Kota } \\
\text { Baru }\end{array}$ & $\begin{array}{l}\text { Kecamatan } \\
\text { Nominatif }\end{array}$ & $\begin{array}{l}\text { Skor } \\
\text { Total }\end{array}$ & $\begin{array}{c}\text { Kabupaten } \\
\text { Lama }\end{array}$ & $\begin{array}{c}\text { Kecamatan } \\
\text { Nominatif }\end{array}$ & $\begin{array}{l}\text { Skor } \\
\text { Total }\end{array}$ \\
\hline 1 & & Tabir Barat & 822 & & Bangko & 1.005 & Merangin & Jangkat & 786 \\
\hline 2 & & Tabir Ulu & 1.019 & & Bangko Barat & 988 & & Sungai Tenang & 1.031 \\
\hline 3 & & Tabir Lintas & 934 & & Batang Mesumai & 1.039 & & Muara Siau & 986 \\
\hline 4 & & Tabir Selatan & 1.089 & & Nalo Tantan & 962 & & Lembah Masurai & 779 \\
\hline 5 & & Tabir Timur & 1.002 & & Pamenang Barat & 958 & & Tiang Pumpung & 1.047 \\
\hline 6 & & Margo Tabir & 1.100 & & Pamenang & 1.041 & & Sungai Manau & 885 \\
\hline 7 & & Tabir & & & Renah Pamenang & 916 & & Renah Pembarap & 955 \\
\hline 8 & & Tabir Ilir & 927 & & $\begin{array}{l}\text { Pamenang } \\
\text { Selatan }\end{array}$ & 1.044 & & Pangkalan Jambu & 1.041 \\
\hline \multicolumn{3}{|c|}{ Jumlah } & 7.974 & & & 7.953 & & & 7.510 \\
\hline \multicolumn{3}{|c|}{ Rata - Rata } & 997 & & & 994 & & & 939 \\
\hline
\end{tabular}

Berdasarkan analisis potensi wilayah Kabupaten Merangin yang diperoleh sebagaimana terlihat pada tabel di atas, maka Pemetaan kecamatan wilayah Kabupaten Merangin pada skenario 5 yaitu kabupaten lama dengan kecamatan nominatif adalah Jangkat, Sungai Tenang, Muara Siau, Lembah Masurai, Tiang Pumpung, Sungai Manau, Renah Pembarap, dan Pangkalan Jambu. Kabupaten baru dengan kecamatan nominatif adalah Tabir Barat, Tabir Ulu, Tabir Lintas, Tabir Selatan, Tabir Timur, Margo Tabir, Tabir, dan Tabir Ilir. Kota baru dengan kecamatan nominatif adalah Bangko, Bangko Barat, Batang 
Mesumai, Nalo Tantan, Pamenang Barat, Pamenang, Renah Pamenang, dan Pamenang Selatan.

Tabel 7. Perbandingan Kemampuan Variabel Kabupaten

\begin{tabular}{l|l} 
No & Variabel \\
\hline 1. & Kependudukan \\
2. & Kemampuan \\
3. & Ekonomi \\
4. & Potensi Daerah \\
5. & Kemampuan \\
6. & Sosial Budaya \\
7. & Sosial Politik \\
8. & Luas Daerah \\
9. & Pertahanan \\
10. & Keamanan \\
\hline Tingkat \\
11. & Kesejahteraan \\
\hline & Rentang Kendali \\
\hline
\end{tabular}
Merangin Dengan Calon Kabupaten

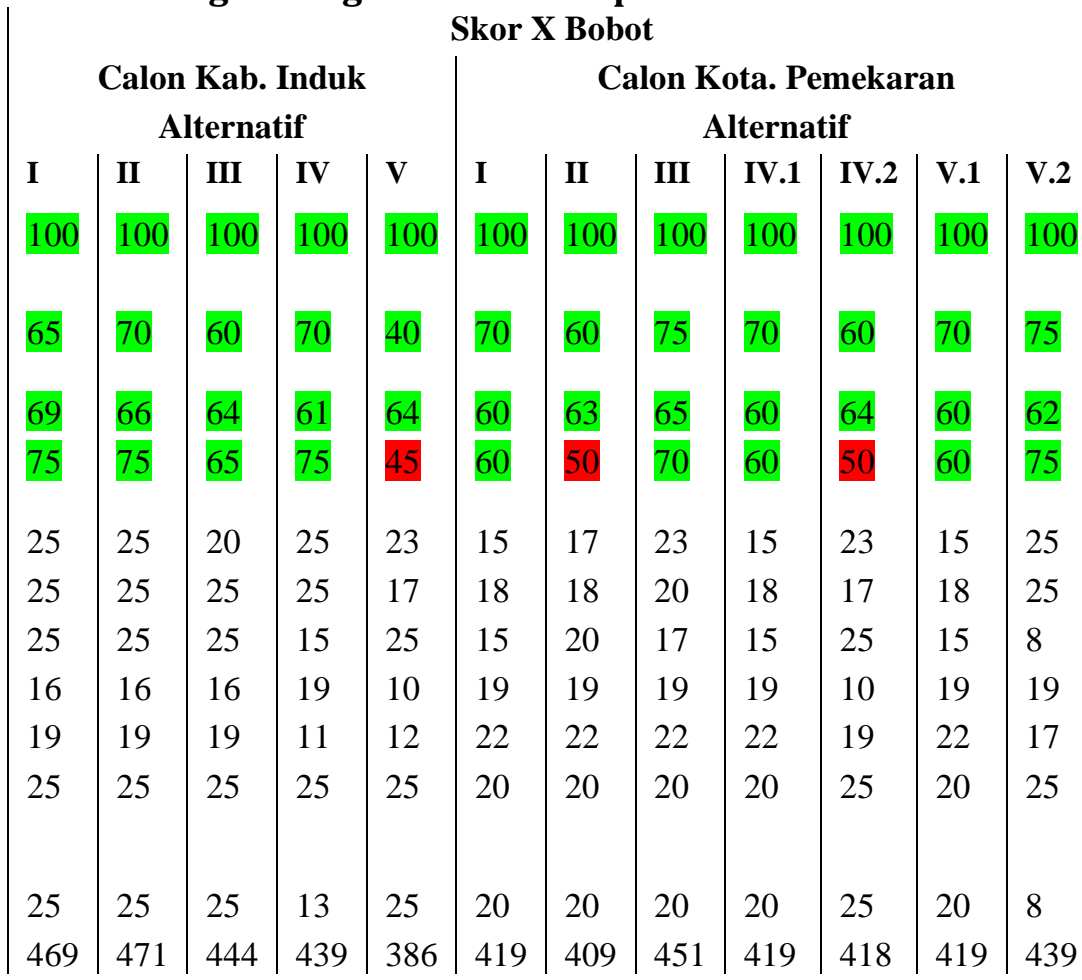

Sumber : Tim Pemekaran Kabupaten Tabir Raya, 2018

\section{Diterima}

\section{Ditolak}

Atas dasar perhitungan di atas, maka dapat dijelaskan hal-hal sebagai berikut :

a. Seluruh calon kabupaten, baik induk maupun pemekaran, dari alternatif I hingga alternatif $\mathrm{V}$ yang dapat direkomendasikan untuk dimekarkan adalah Alternatif I (Induk 16 Kecamatan dengan skor 469, Kabupaten Baru 8 Kecamatan dengan Skor 419) dan Alternatif III (Induk 14 Kecamatan dengan skor 444, Kabupaten Baru 10 Kecamatan dengan Skor 451) karena berdasarkan hasil analisis semuanya variabel masuk ketegori Sangat Mampu (420-500) sehingga dapat direkomendasikan untuk menjadi daerah otonom baru. Selain itu kedua alternatif (I dan III) semuanya memenuhi syarat kelulusan yang diatur dalam PP No. 78 Tahun 2007 bahwa untuk 4 (empat) faktor utama harus memenuhi standar yaitu kependudukan (80-100), kemampuan ekonomi (60-75), potensi daerah (60-75), dan kemampuan keuangan (60-75).

b. Prinsip utama dalam melakukan pemekaran wilayah adalah Pemekaran kabupaten tidak boleh mengakibatkan calon kabupaten induk nantinya menjadi lemah atau tidak mampu menjalankan otonominya, atau perbedaan kemampuan antara calon kabupaten yang akan dibentuk dan calon kabupaten induk setelah terjadi pemekaran tidak boleh memiliki kesenjangan yang tajam.

Berangkat dari 2 alternatif di atas maka Tim Kajian Akademis menyarankan menurut perhitungan bahwa: 
a. Usulan Pertama : Alternatif I diprioritaskan Pertama

1) Calon Kabupaten Induk :

16 Kecamatan yaitu Jangkat, Sungai Tenang, Muara Siau, Lembah Masurai, Tiang Pumpung, Pamenang, Pamenang Barat, Renah Pamenang, Pamenang Selatan, Bangko, Bangko Barat, Batang Mesumai, Nalo Tantan, Sungai Manau, Renah Pembarap dan Pangkalan Jambu.

2) Calon Kabupaten Pemekaran :

8 Kecamatan yaitu Tabir Barat, Tabir Ulu, Tabir Lintas, Tabir Selatan, Tabir, Margo Tabir, Tabir Ilir dan Tabir Timur.

b. Usulan Kedua : Alternatif III diprioritaskan Kedua

1) Calon Kabupaten Induk :

14 Kecamatan yaitu Jangkat, Sungai Tenang, Muara Siau, Lembah Masurai, Tiang Pumpung, Renah Pemanang, Pamenang Selatan, Bangko, Bangko Barat, Batang Mesumai, Nalo Tantan, Sungai Manau, Renah Pembarap, dan Pangkalan Jambu.

2) Calon Kabupaten Pemekaran:

10 Kecamatan yaitu Tabir Barat, Tabir Ulu, Tabir Lintas, Tabir Selatan, Pemenang Barat, Pemenang, Tabir, Margo Tabir, Tabir Ilir, danTabir Timur.

Berdasarkan kajian akademis tersebut maka Tim Pemekaran Daerah Kabupaten Tabir Raya menyepakati bahwa alternatif 1 merupakan pilihan terbaik dalam mewujudkan kabupaten baru, hal ini juga didasari pertimbangan bahwa kecamatan dalam wilayah Tabir merupakan kecamatan yang satu rumpun.

6. Persetujuan Bupati Merangin

Hasil Kajian Akademis yang dilakukan oleh Tim Pemerintah Kabupaten Merangin Bekerjasama dengan Institut Pemerintahan Dalam Negeri-Kemendagri tentang Pembentukan Daerah Otonom Baru (Pemekaran Wilayah) Kabupaten Merangin Provinsi Jambi, yang diketuai oleh Prof. Dr. Sadu Wasistiono, MS selaku Guru Besar Manajemen Pemerintahan dan Otonomi Daerah menjadi pertimbangan bagi Pemerintah Daerah Kabupaten Merangin untuk menyetujui atau menolak pemekaran Kabupaten Tabir Raya. Pemekaran wilayah Kabupaten Merangin menjadi dua kabupaten telah disetujui secara lisan oleh bupati sebelumnya yakni Pak Nalim, hanya saja kajian akademisnya belum ada, baru pada tahun 2015 dilakukan Kajian Akademis, hal ini tidak terlepas dari dana, karena waktu itu dana yang dimiliki sangan minim sekali.

Berdasarkan dokumen yang diperolah dari Tim Pemekaran Kabupaten Tabir Raya diketahui pada Tahun 2015 Pemerintah Kabupaten Merangin telah mengeluarkan Keputusan Bupati Merangin Nomor 201/PEM/2015 tentang Persetujuan Pemekaran Kabupaten Merangin, dimana dasar pertimbangan yang disampaikan adalah aspirasi masyarakat Tabir dari 8 kecamatan, serta hasil kajian akademis pembentukan daerah otonom baru di Kabupaten Merangin oleh Tim Kajian dari Institut Pemerintah Dalam Negeri.

Selanjutnya Pemerintah Kabupaten Merangin mengeluarkan Keputusan Bupati Merangin Nomor 202/PEM/2015 tentang Persetujuan Penetapan Lokasi Calon Ibu Kota Daerah Otonom Baru Kabupaten Tabir Raya, dimana dasar pertimbangannya bahwa dalam 
rangka pelaksanaan pemekaran Kabupaten Merangin menjadi Daerah Otonom Baru Kabupaten Tabir Raya dan untuk meningkatkan kualitas penyelenggaraan tugas-tugas pemerintahan, pembangunan, dan kemasyarakatan serta memperhatikan kondisi objektif daerah otonom baru hasil hasil kajian akademis pembentukan daerah otonom baru di Kabupaten Merangin oleh Tim Kajian dari Institut Pemerintah Dalam Negeri.

Pemerintah Kabupaten Merangin juga mengeluarkan Keputusan Bupati Merangin Nomor 203/PEM/2015 tentang Persetujuan Pemberian Dana Hibah Untuk Penyelenggaraan Pemerintah Daerah Otonom Baru Kabupaten Tabir Raya, dimana dasar pertimbangannya adalah bahwa dalam rangka melaksanakan otonomi daerah secara berdaya guna dan berhasilguna dalam upaya memperlancar dan meningkatkan penyelenggaraan pemerintahan, pelaksanaan pembangunan dan pelayanan kepada masyarakat serta dalam upaya menampung dan mendukung aspirasi masyarakat terhadap pembentukan daerah otonom baru Kabupaten Tabir Raya maka perlu ditetapkan dukungan dana hibah untuk penyelenggaraan pemerintahan daerah otonom baru Kabupaten Tabir Raya yang ditetapkan melalui Anggaran Pendapatan dan Belanja Daerah Kabupaten Merangin selama 3 (tiga) tahun berturut-turut.

Berikut merupakan dukungan pendanaan dari Pemerintah Daerah Kabupaten Merangin terhadap pembentukan Kabupaten Tabir Raya:

\section{Tabel 8. Dukungan Pendanaan dari Pemda Merangin}

Pemerintah Kabupaten Merangin pun sudah mengeluarkan Keputusan Bupati Merangin Nomor 204/PEM/2015 tentang Persetujuan Pelepasan Kecamatan yang Menjadi Cakupan Daerah Otonom Baru Kabupaten Raya, dengan dasar pertimbangan bahwa dalam rangka pelaksanaan pemekaran Kabupaten Merangin menjadi Daerah Otonom Baru Kabupaten Tabir Raya sebagai upaya peningkatakan pelayanan kepada masyarakat, pelaksanaan pemerintahan dan pembangunan, serta sebagai wujud dari aspirasi masyarakat perlu ditetapkan persetujuan pelepasan kecamatan yang menjadi cakupan daerah otonom baru Kabupaten Raya.

Pemerintah Kabupaten Merangin juga mengeluarkan Keputusan Bupati Merangin Nomor 205/PEM/2015 tentang Persetujuan Pemberian Dana untuk Penyelenggaraan Pilkada Pertama Kali bagi Daerah Otonom Baru Kabupaten Raya, dimana dasar pertimbangannya adalah bahwa dalam rangka melaksanakan otonomi daerah secara berdaya guna dan berhasilguna dalam upaya memperlancar dan meningkatkan penyelenggaraan pemerintahan, pelaksanaan pembangunan dan pelayanan kepada masyarakat serta dalam upaya menampung dan mendukung aspirasi masyarakat terhadap pembentukan daerah otonom baru Kabupaten Tabir Raya maka perlu ditetapkan berupa pemberian dana untuk penyelenggaraan Pilkada Pertama Kali bagi daerah otonom baru Kabupaten Tabir Raya yang ditetapkan melalui Anggaran Pendapatan dan Belanja Daerah Kabupaten Merangin.

Pemerintah Kabupaten Merangin pun mengeluarkan Keputusan Bupati Merangin Nomor 206/PEM/2015 tentang Persetujuan Penyerahan Sarana dan Prasarana Perkantoran Untuk Daerah Otonom Baru Kabupaten Raya, dimana dasar pertimbangannya adalah bahwa dalam rangka melaksanakan otonomi daerah secara berdaya guna dan 
berhasilguna dalam upaya memperlancar dan meningkatkan penyelenggaraan pemerintahan, pelaksanaan pembangunan dan pelayanan kepada masyarakat serta dalam upaya menampung dan mendukung aspirasi masyarakat terhadap pembentukan daerah otonom baru Kabupaten Tabir Raya maka perlu adanya penyerahan sarana dan prasana perkantoran yang terdapat dalam wilayah cakupan Daerah Otonom Baru Kabupaten Raya.

Pemerintah Kabupaten Merangin juga telah mengeluarkan Keputusan Bupati Merangin Nomor 207/PEM/2015 tentang Persetujuan Penyerahan Kekayaan Daerah Untuk Daerah Otonom Baru Kabupaten Raya, dimana dasar pertimbangannya adalah bahwa dalam rangka melaksanakan otonomi daerah secara berdaya guna dan berhasilguna dalam upaya memperlancar dan meningkatkan penyelenggaraan pemerintahan, pelaksanaan pembangunan dan pelayanan kepada masyarakat serta dalam upaya menampung dan mendukung aspirasi masyarakat terhadap pembentukan daerah otonom baru Kabupaten Tabir Raya maka perlu adanya penyerahan kekayaan daerah yang terdapat dalam wilayah cakupan Daerah Otonom Baru Kabupaten Raya.

7. Persetujuan DPRD Kabupaten Merangin

Berdasarkan berbagai pertimbangan dan kajian akademis serta memperhatikan aspirasi dari masyarakat maka DPRD Kabupaten Merangin menyetujui pemekaran Tabir Raya dari Kabupaten Merangin yang diputuskan dalam Sidang Paripurna DPRD Kabupaten Merangin Tahun 2015. Persetujuan DPRD Kabupaten Merangin mempertimbangkan Tim kajian akademis dan persetujuan dari Pemerintah Kabupaten Merangin yang dalam hal ini keputusan Bupati Merangin, dan Pansus DPRD Merangin maka secara bulat keputusan DPRD Kabupaten Merangin menyetujui pemekaran Tabir Raya yang diputuskan dalam Sidang Paripurna.

8. Persetujuan Pemerintah Provinsi Jambi

Hasil dari berbagai pertimbangan dan usulan dari Pemerintah Kabupaten Merangin serta memperhatikan aspirasi dari masyarakat melalui DPRD Kabupaten Merangin maka Pemerintah Provinsi Jambi menyetujui pemekaran Tabir Raya dari Kabupaten Merangin yang diputuskan Keputusan Gubernur Jambi Nomor 363/KEP.GUB/SETDA. PEM-4.1/2015 tentang Persetujuan Pemekaran Kabupaten Merangin Menjadi Kabupaten Merangin dan Kabupaten Tabir Raya. Dasar pertimbangannya adalah memenuhi syarat administratif, teknis dan fisik kewilayahannya maka harus memperoleh persetujuan Gubernur yang bersangkutan.

9. Persetujuan DPRD Provinsi Jambi

Keputusan Gubernur Jambi Nomor 363/KEP.GUB/SETDA. PEM4.1/2015 tentang Persetujuan Pemekaran Kabupaten Merangin Menjadi Kabupaten Merangin dan Kabupaten Tabir Raya menjadi dasar pertimbangan bagi DPRD Provinsi Jambi dalam memberikan persetujuan terhadap pembentukan kabupaten baru yakni Kabupaten Tabir Raya. Berdasarkan hasil lobi anggota DPRD Provinsi Jambi daerah Pemilihan Merangin dan Sarolangun serta dukungan berbagai tokoh Merangin di Provinsi Jambi serta kerja keras Tim Pemekaran Tabir Raya akhirnya diperoleh persetujuan dari DPRD Provinsi Jambi.

10. Pemetaaan Wilayah

Setelah semua persetujuan yang dipersyaratkan dan berkas dilengkapi, maka Tim Pemekaran Tabir Raya dari Kabupaten Merangin 
menyerahkan proposal pembentukan Kabupaten Tabir Raya ke Kementerian Dalam Negeri di Jakarta. Hasil kajian dari Kementerian Dalam Negeri mengharuskan Pemerintah Kabupaten (Pemkab) Merangin membuat peta wilayah, sebab ada beberapa syarat pemekaran Tabir Raya tersebut belum dipenuhi Pemerintah Kabupaten (Pemkab) Merangin. syarat yang belum dipenuhi tersebut yang merupakan syarat mutlak itu adalah peta wilayah calon daerah otonomi baru (DOB) dan peta wilayah kabupaten induk.

Kondisi tersebut menggambarkan bahwa secara adminitrasi tidak ada permasahan. Namun syarat mutlak seperti peta wilayah yang masih dalam proses, dimana ada tiga syarat peta yang diminta, peta calon kabupaten baru, peta kabupaten induk dan peta kabupaten induk jika sudah pisah dengan Tabir raya.

\section{Faktor-Faktor Penghambat Pemekaran Tabir Raya Menjadi Kabupaten}

Keinginan masyarakat delapan kecamatan Tabir, untuk berpisah dari kabupaten Merangin, nampaknya belum bisa terpenuhi dalam waktu dekat ini. Sebab ada beberapa syarat pemekaran tabir raya tersebut belum dipenuhi Pemerintah Kabupaten (Pemkab) Merangin, diantaranya:

1. Peta Wilayah

Kendala yang dihadapi oleh Pemerintah Kabupaten Merangin dan TIM Pemekaran Tabir Raya adalah Peta Wilayah, karena Peta ini merupakan salah satu penilai yang sangat mendukung pemekaran, sedangkan biaya untuk pembuatan peta tersebut cukup mahal. Hal ini sebagaimana disampaikan oleh Bapak Zakaria selaku Ketua Tim Pemekaran Tabir Raya:

“...peta itu kan bukan kita yang buatnya, yang buatnya yaitu BIG (Badan Informasi Geospasial) untuk membuat Peta wilayah, karena wilayah merangin ini luas tentunya butuh dana besar, sedangkan kemampuan keuangan Pemerintah Merangin sangat terbatas, namun Alhamdulilah kita bisa akali dengan cara bertahap selama beberapa tahun..."

Pernyataan tersebut menggambarkan bahwa kemampuan keuangan Pemerintah Merangin sangat terbatas sehingga untuk membuat Peta wilayah belum mampu membiaya BIG (Badan Informasi Geospasial), karena wilayah merangin ini luas tentunya butuh dana besar.

2. Peraturan Pemerintah

Setelah semuanya lengkap maka tahapan terahkhirnya adalah diterbitkannya Peraturan Pemerintah yang mengatur tentang Pemekaran Daerah Otonom Baru, hanya saja hal tersebut belum terwujud, dikarenakan masih berproses.

Upaya Tim Pemekaran Tabir Raya dalam mengatasi hambatan dalam pemekaran Tabir Raya dari Kabupaten Merangin

Tim Pemekaran Tabir Raya dalam berusaha untuk mengatasi hambatan dalam pemekaran Tabir Raya dari Kabupaten Merangin. Upaya tersebut didukung Pemerintah Kabupaten Merangin yang serius mengupayakan pembentukan Kabupaten Tabir Raya. Upaya yang dilakukan adalah:

1. Percepatan Pembuatan Peta

Pada hari Senin tanggal 26 Juni 2018 Bupati Merangin Al-Haris bersama Wakilnya Khafied Moein, Ketua DPRD Merangin, dan unsur pemerintah serta stakeholder terkait melakukan pengesahan dan penandatangan peta Kabupaten Tabir Raya. Usai acara Penandatanganan Draf Peta wilayah Bupati Merangin Al Haris mengatakan, jika penandatanganan tersebut merupakan salah satu persaratan yang segera dilakukan mengingat hal tersebut merupakan 
persyaratan percepatan pemekaran Tabir Raya. Pemekaran Tabir Raya sendiri sudah memasuki progres yang sangat baik, mengingat persiapan pemekaran sudah hampir 100 persen, dari ratusan Kabupaten yang ingin dimekarkan di Indonesia, Jadi semua berlomba. Alhamdulillah Kabupaten Tabir Raya Persiapan sudah hampir 100 Persen, tinggal menunggu pembahasan dan pengesahan dari Presiden.

2. Peraturan Pemerintah

Upaya yang dilakukan pemerintah Kabupaten Mernagin dan Tim Pemekaran adalah mendorong pemerintah Pusat agar segera mengesahkan peraturan pemerintah mengenai pemekaran wialayah Tabir Raya menjadi Kabupaten Baru.

\section{Penutup}

Kesimpulan dari penelitian ini adalah 1) Proses pemekaran Kabupaten Tabir Raya dari Kabupaten Merangin telah berjalan lebih kurang 10 tahun, beberapa tahapan yang telah dilalui adalah a. Inisiasi, b. Rapat, c. Penggalangan dana, d. Kajian Akademis, e. Persetujuan kabupaten induk, f. Persetujuan DPRD Kabupaten Merangin, g. Persetujuan dari Pemerintah Provinsi Jambi, h. Persetujuan dari DPRD, i. Proses di Kementerian Dalam Negeri, j. Pemetaan wilayah. 2) Faktor penghambat pemekaran Kabupaten Tabir Raya dari Kabupaten Merangin adalah: a. Peta Wilayah dan b. Peraturan Pemerintah. 3) Tim Pemekaran Tabir Raya dalam berusaha untuk mengatasi hambatan dalam pemekaran Tabir Raya dari Kabupaten Merangin. Upaya tersebut antara lain adalah: a. Percepatan Pembuatan Peta dan b. Penerbitan Peraturan Pemerintah.

Saran dari penulis adalah diharapkan partisipasi aktif dari pemerintah Kabupaten Merangin untuk mendorong percepatan pemekaran Tabir Raya menjadi Kabupaten baru dan juga diharapkan masyarakat dan pihak terkait memberikan dukungan main moril maupun penggalangan dana guna terwujudnya kabupaten baru yang mandiri dan mensejahterakan masyarakat.

\section{Referensi}

Abdullah, Rozali. (2005). Pelaksanaan Otonomi Luas Dengan Pemilihan Kepala Daerah Secara Langsung. Jakarta. PT.Raja Grafindo Persada.

Manan, Bagir., (2001). Menyongsong fajar Otonomi Dearah. Pusat Studi Hukum Fakultas Hukum UII Yogyakarta.

Mardiasmo., (2002). “Otonomi dan Manajemen Keuangan Daerah". ANDI.

Moleong, Lexi J., (2002). Metodelogi Penelitian Kualitatif. PT. Remaja Rosda Karya.

Pemerintah Republik Indonesia. (2014). Undang-undang Republik Indonesia Nomor 23 Tahun 2014 tentang Pemerintahan Daerah Bab VI Penataan Daerah Pasal 31.

Poerwadarminta, W.J.S. (2005). Kamus Umum Bahasa Indonesia. Edisi Ketiga. Balai Pustaka.

Ratnawati, Tri. (2006). Mengevaluasi Kebijakan Pemekaran Wilayah di Indonesia (dalam M.Zaki Mubarak dkk (ed.) "Blue Print Otonomi Daerah"). YHB Kemitraan dan UE.

Risal, M. (2017). Kearifan Lokal Dalam Pembentukan Daerah Otonomi Baru Di Era Otonomi Daerah (Studi Kasus: Kearifan Lokal Di Daerah Apau Kayan Kabupaten Malinau). Jurnal Administrative Reform, 4(2), 106-126.

Seymour, R., \& Turner, S. (2002). Otonomi daerah: Indonesia's decentralisation experiment. New Zealand Journal of Asian Studies, 4, 33-51.

Sugiyono. (2010). Metode Penelitian Kuantitatif Kualitatif \& RND. Bandung : Alfabeta. 